\title{
The Effect of Tomato Juice in Increasing Ki-67 Expression and Epithelial Thickness on The Vaginal Wall of Menopausal Rats
}

\author{
Juminten Saimin ${ }^{1, *}$, Hendy Hendarto², Soetjipto ${ }^{3}$ \\ ${ }^{1}$ Department of Obstetrics and Gynecology, Faculty of Medicine, Universitas Halu Oleo, Kampus Bumi Tridharma Andonouhu, Kendari, Indonesia \\ ${ }^{2}$ Department of Obstetrics and Gynecology, Faculty of Medicine, Universitas Airlangga, Kampus A, Jl. Mayjen Prof. Dr. Mustopo 47, Surabaya, Indonesia \\ ${ }^{3}$ Department of Biochemistry, Faculty of Medicine, Universitas Airlangga, Kampus A, Jl. Mayjen Prof. Dr. Mustopo 47, Surabaya, Indonesia \\ ${ }^{*}$ Corresponding author. E-mail: intaz.sarana@yahoo.com
}

Received date: Aug 19, 2018; Revised date: Jan 9, 2019; Accepted date: Jan 11, 2019

\section{Abstract}

B ACKGROUND: Dyspareunia and pain due to the decrease of vaginal wall thickness usually happen in menopausal women. The reduction of estrogen levels cause the decreasing of cell proliferation and the thinning of vaginal wall epithelium. Tomato (Solanum lycopersicum) is a source of phytoestrogens, which produce estrogenic effects. This study aims to assess the effect of tomato juice on Ki-67 expression and epithelial thickness of the vaginal wall in menopausal rats.

METHODS: This was an experimental study using Sprague-Dawley rats. Twenty-four female rats, aged 4 months and weighing 150-200 grams, were divided into 4 groups. Each group consisted of 6 rats. Negative control (NC) group was group of rats with sham procedure and performed by distilled water for 28 days. Positive control (PC) group was group of bilateral ovariectomized rats and performed by distilled water for 28 days. The first treatment (T1) group was group of bilateral ovariectomized rats, given tomato juice at dose of $11 \mathrm{~g} / 200 \mathrm{~g}$ body weight (BW)/day. The second treatment (T2) group was group of bilateral ovariectomized rats, given tomato juice at dose of $15 \mathrm{~g} / 200 \mathrm{~g}$
BW/day. Data analysis was done with Anova, multiple comparisons and regression test.

RESULTS: The group with lowest Ki-67 expression was PC group (2.52 \pm 0.60$)$. The expression of Ki-67 in treatment groups (T1 and T2) was higher than PC group, but lower than NC group. There was no significant difference between groups $(p=0.771)$. The lowest epithelial thickness was found in PC group (21.19 \pm 3.96$)$ and the highest was found in the treatment groups $(38.73 \pm 12.43)$. There was positive correlation between tomato juice and epithelial thickness $(p=0.647)$.

CONCLUSION: Tomato juice increases Ki-67 expression and epithelial thickness on the vaginal wall of menopausal rats. The increase of epithelial thickness follows the administration dose, but Ki-67 expression does not exceed in the control rats. Tomato juice increases the cell proliferation of vaginal wall on menopausal rats, however the increase is still within normal limits.

KEYWORDS: epithelial thickness, Ki-67, menopause, tomato juice

Indones Biomed J. 2019; 11(2): 152-8

\section{Introduction}

Urogenital tracts are very sensitive organs to estrogen decline. Almost half of post-menopausal women are experiencing symptoms associated with urogenital atrophy.(1) The vagina is a biological indicator that is sensitive to the decrease and low levels of estrogen in postmenopausal women. Some menopausal women complain about the burning sensation in the vulva, dyspareunia and pain due to the decreased elasticity and thickness of the vaginal wall. Around $75-85 \%$ of post-menopausal women are experiencing vaginal atrophy. Symptoms of atrophic vaginitis are often complained by $42-54 \%$ of menopausal 
women.(2) Meanwhile, 48\% of post-menopausal women are having dyspareunia due to dry vagina. Dyspareunia has a significant impact on sexual activity, disrupting household harmony and affecting the quality of life of menopausal women. $(3,4)$

At menopause age, the loss of estrogen production by the ovary causes the decrease of estrogen levels, which results in reduced rugae, thinning of the vaginal epithelium and vaginal atrophy. Thinning of the vaginal mucosal epithelium occurs due to the decreased of cell proliferation. Estrogen deficiency changes the maturation of epithelial cells, which makes the epithelial layer that is mostly composed of parabasal cells, so that the glycogen content will be decreased.(5) Glycogen reduction in the vaginal epithelial causes an increase in vaginal $\mathrm{pH}$ which increases the risk of vaginal infections and atrophic vaginitis. $(2,6)$

Management of menopausal symptoms is hormone replacement therapy (HRT) which used estrogen. This therapy effectively increases estrogen, but is reported to have long-term adverse effects, such as increasing the risk of breast cancer, heart disease and stroke.(1)

Several studies have used phytoestrogens as a source of natural estrogen derived from plants for the treatment of menopausal symptoms.(7) Phytoestrogens have a very high affinity for estrogen- $\beta$ receptors. Phytoestrogens have estrogenic effect like endogenous estrogen. The bond between phytoestrogens and receptors will trigger the intracellular signals, thus activating the transcription process to produce proteins that induce cell proliferation and epithelial maturation, so the thickening of the epithelial lining on the vaginal surface happpen.(8)

$\mathrm{Ki}-67$ antigen is a nuclear protein that plays a role in cell proliferation which is associated with transcription of ribonucleic acid (RNA).(9) Several studies have found that cell proliferation is related to the expression of $\mathrm{Ki}$ 67. $\mathrm{Ki}-67$ is a non-histone protein located at the core. By using Ki-67 monoclonal antibody, cell proliferation will be detected because these antibodies will only be expressed in proliferative cells. $(10,11)$

Tomatoes (Solanum lycopersicum) have been reported to contain high phytoestrogen. There have been many publications describing the role of phytoestrogens in menopause.(7) Tomato juice was proven to increase estradiol levels of rats after ovariectomy. The control group showed the lowest level of estradiol, while the highest result was found on treatment.(12) Phytoestrogens induce cell proliferation and epithelial maturation so that there is thickening of the epithelial lining on the vaginal surface.(8) The cell proliferation is related to Ki-67 expression. $(10,11)$ However, the relationship between Ki-67 as a biomarker of cell proliferation and epithelial thickness of the menopausal vaginal wall on tomato juice administration remains unclear. Therefore, the aim of this study was to assess the effect of tomato juice on $\mathrm{Ki}-67$ expression and menopausal vaginal wall epithelial thickness, so that it can be seen whether the administration of tomato juice will increase epithelial thickness of the menopausal vaginal wall and will continue to trigger an increase in proliferation.

\section{Methods}

This study was an experimental study using SpragueDawley rats. Research material was tomato fruit with the same variety picked on 80-90 days after planting, came from the same tomato plantation in Malang and was certified by the Indonesian Institute of Sciences, Plant Conservation Center, Purwodadi Botanical Garden in East Java, Indonesia. Tomatoes were processed using electric juicers until the inner tomato juice was separated from the skin and seeds. Determination of tomato dose was based on the conversion of human to experimental doses, which was 0.018 from the human consumption dose of 400 grams/day to 7.2 grams/200 grams of rat body weight (BW). Treatment of animals models were conducted at the experimental animal enclosure of the Faculty of Veterinary Medicine, Universitas Airlangga. Immunohistochemistry (IHC) staining for Ki-67 expression and HematoxylinEosin (HE) staining for measurement of epithelial thickness were conducted at the Veterinary Pathology Laboratory, Faculty of Veterinary Medicine, Universitas Airlangga. Ethical clearance was obtained from Ethics Committee of Faculty of Veterinary Medicine, Universitas Airlangga, with number: 2.KE.024.02.2018.

\section{Treatment of Rats}

The study was conducted on twenty-four healthy female rats, 4 months old and weighing 150-200 grams, starting with acclimatization for two weeks. The rats were kept in plastic cages with floors of wood shavings and covered with wire mesh measuring $20 \times 40 \times 15 \mathrm{~cm}$ to ensure the air circulation. The cage was placed in a ventilated room and natural air. Each cage was filled with 3 rats. The rats were given distilled water and rat feed in ad libitum, in the form of pellets. Rats were divided into 4 treatment groups randomly, each group consisted of 6 rats. The negative control (NC) group was rats carried out by a sham procedure. The rats had abdominal incision but not ovariectomized, and treated with distilled water for 28 days. The positive control (PC) group was bilateral ovariectomized rats and 
treated with distilled water for 28 days. This group showed menopausal condition but treated without tomato juice. The first treatment (T1) group, based on the results of previous studies, was bilateral ovariectomized rats and treated with tomato juice at a dose of $11 \mathrm{~g} / 200 \mathrm{~g} \mathrm{BW} /$ day. The second treatment (T2) group was bilateral ovariectomized rats and treated tomato juice with the dose of 15 grams/200 grams of rat BW/day. The menopausal condition was confirmed by the vaginal swab which showed the diestrus condition on the $21^{\text {st }}$ day after bilateral ovariectomy. Rats were sacrificed on the $29^{\text {th }}$ day of treatment for tissue retrieval. The sample was made by taking the vaginal wall about 1 $\mathrm{cm}$ and making paraffin blocks. The paraffin block of the vaginal wall was sliced using a microtome with thickness of $4 \mu \mathrm{m}$. Observations were carried out by a pathologist using the blind method.

\section{HE Staining and Epithelial Thickness Measurement}

Microtome slashed vaginal section was placed on the object glass and then deparaffinised and stained with HE. Observations and calculations were carried out using a microscope by a pathologist using the blind method.

\section{IHC Staining of Ki-67 Expression}

Immunohistochemistry staining of Ki-67 expression was performed by soaking the object glass from paraffin block in xylol 2 times for 5 minutes each. After that it was rehydrated using serial alcohol (absolute, 96\%, 80\%, $70 \%, 30 \%$ and $5 \%$ ) for 5 minutes, respectively, then rinsed in double-distilled water $\left(\mathrm{dH}_{2} \mathrm{O}\right)$ for 5 minutes. Slide was washed with phosphate buffered saline (PBS) pH 7.4 once for 5 minutes. Endogenous peroxide blocking used 3\% hydrogen peroxide $\left(\mathrm{H}_{2} \mathrm{O}_{2}\right)$ for 20 minutes. It was washed by PBS pH 7.4 three times for 5 minutes. Unspecified protein blocking used $5 \%$ fetal bovine serum (FBS) containing $0.25 \%$ Triton X-100 and it was washed by PBS pH 7.4 three times for 5 minutes. Then, it was incubated by Ki-67 primary antibody, Ki-67 sc-23900 (Santa Cruz Biotechnology, Dallas, USA) for 60 minutes. After that it was washed using PBS pH 7.4 three times for 5 minutes. It was incubated by horseradish peroxidase (HRP) conjugated rabbit for 40 minutes and washed using PBS pH 7.4 three times for 5 minutes. It was dripped with diamino benzidine and incubated for 10 minutes. It was washed using PBS pH 7.4 three times for 5 minutes and washed using $\mathrm{dH}_{2} 0$ for 5 minutes. Counterstaining used Hematoxylin-Mayer that was incubated for 10 minutes, washed using tap water, and rinsed using $\mathrm{dH}_{2} \mathrm{O}$ and dried. Mounting used the attachment and closes with a glass cover.
Ki-67 expression was measured according to the Immuno Reactive Score (IRS). IRS was a semi-quantitative assessment according to the modified Remmele method. The Remmele Scale Index was the result of multiplication between the percentage scores of positive immune-reactive cells with color intensity scores in immune-reactive cells. The color intensity was yellowish brown (score 1), medium brown (score 2) and dark brown (score 3). Data for each sample was the average IRS observed in five different View Fields at 400x magnifications. Observations and calculations were carried out using a microscope by a pathologist using the blind method.

\section{Statistics Analysis}

For statistical analysis, analysis of variance (ANOVA) was used, followed by multiple comparison test using Tukey Honest Significant Difference (HSD). The correlation between the various doses of tomato juice with expression of Ki-67 and epithelial thickness of the vaginal wall used regression test. The $p$-value $<0.05$ was considered to indicate the statistical significance.

\section{Results}

\section{Effect of Tomato Juice on Ki-67 Expression}

Table 1 showed that the highest expression of Ki-67 was found in the NC group (3.12 \pm 1.74$)$ and the lowest was in the PC group (2.52 \pm 0.60$)$. Expression of Ki-67 in the treatment group (T1 and T2) was higher than the PC group, but lower than the NC group. From Kolmogorov-Smirnov normality test, data with normal distribution $(p>0.05)$ was obtained. And from one way ANOVA test, there was no significant difference between groups $(p=0.771)$. This showed that tomato juice increased the expression of Ki-67 but the increase was not significant. The homogeneity test of the variant Ki-67 expression data was homogeneous ( $p>0.05)$, so the multiple comparisons analysis test was performed using Tukey HSD test. The multiple comparisons test appears that there was no significant difference of Ki-67 expression in groups $(p>0.05)$. These results indicated that tomato juice increased the expression of Ki-67 even though the increase did not reach normal conditions as in the $\mathrm{NC}$ group. The dose of tomato juice does not significantly affect the increase of $\mathrm{Ki}-67$ expression.

Figure 1 showed the Ki-67 expression, which was characterized by brown chromogen in the nucleus. Ki-67 expression in the $\mathrm{NC}$ group is higher than the treatment group (T1 and T2) and the PC group. 
Table 1. Multiple comparisons of Ki-67 expression.

\begin{tabular}{cccccc}
\hline \multirow{2}{*}{ Groups } & \multicolumn{5}{c}{ Tukey HSD } \\
\cline { 2 - 5 } & NC & PC & T1 & T2 & -value \\
\hline NC (3.12 \pm 1.74$)$ & - & 0.722 & 0.977 & 0.948 & \\
PC $(2.52 \pm 0.60)$ & & - & 0.916 & 0.955 & \\
T1 $(2.92 \pm 0.68)$ & & & - & 0.999 & 0.771 \\
T2 $(2.83 \pm 0.87)$ & & & & - & \\
\hline
\end{tabular}

* Significancy value $p<0.05$, was tested with ANOVA test. NC: negative control group; PC: positive control group; T1: the first treatment group; T2: the second treatment group.

\section{Effect of Tomato Juice on the Vaginal Wall Epithelial Thickness}

Table 2 showed that the lowest epithelial thickness was found in the PC group (21.19 \pm 3.96$)$ and the highest was in the T2 group (38.73 \pm 12.43$)$. The $\mathrm{T} 1$ group was lower than $\mathrm{T} 2$, but was higher than the PC group. From Kolmogorov-Smirnov test, data with normal distribution $(p>0.05)$ was obtained. And from ANOVA test, significant differences results were obtained $(p=0.003)$. homogeneous data was obtained from the Levene homogeneity test obtained $(p>0.05)$. Multiple comparisons with Tukey HSD test showed that there were significant differences of vaginal wall epithelial thickness $(p<0.05)$. It showed that tomato juice significantly increased epithelial thickness and the higher the dose of tomato juice, the higher the thickness would be. The regression analysis showed that the standard coefficient was positive $(b=0.647)$, meaning that the increase of tomato juice would increase the expression of epithelium thickness.

The examination of thickness of the epithelial layer of vaginal wall was shown in Figure 2. The vaginal mucosal layer consisted of a flat-lined epithelium without horns, beneath the epithelium there was a lamina propria consisting of dense connective tissue with many blood vessels. The black arrows showed that the epithelial layer of vaginal wall in the T2 group was thicker than the $\mathrm{NC}$ group, $\mathrm{T} 1$ group and PC group.
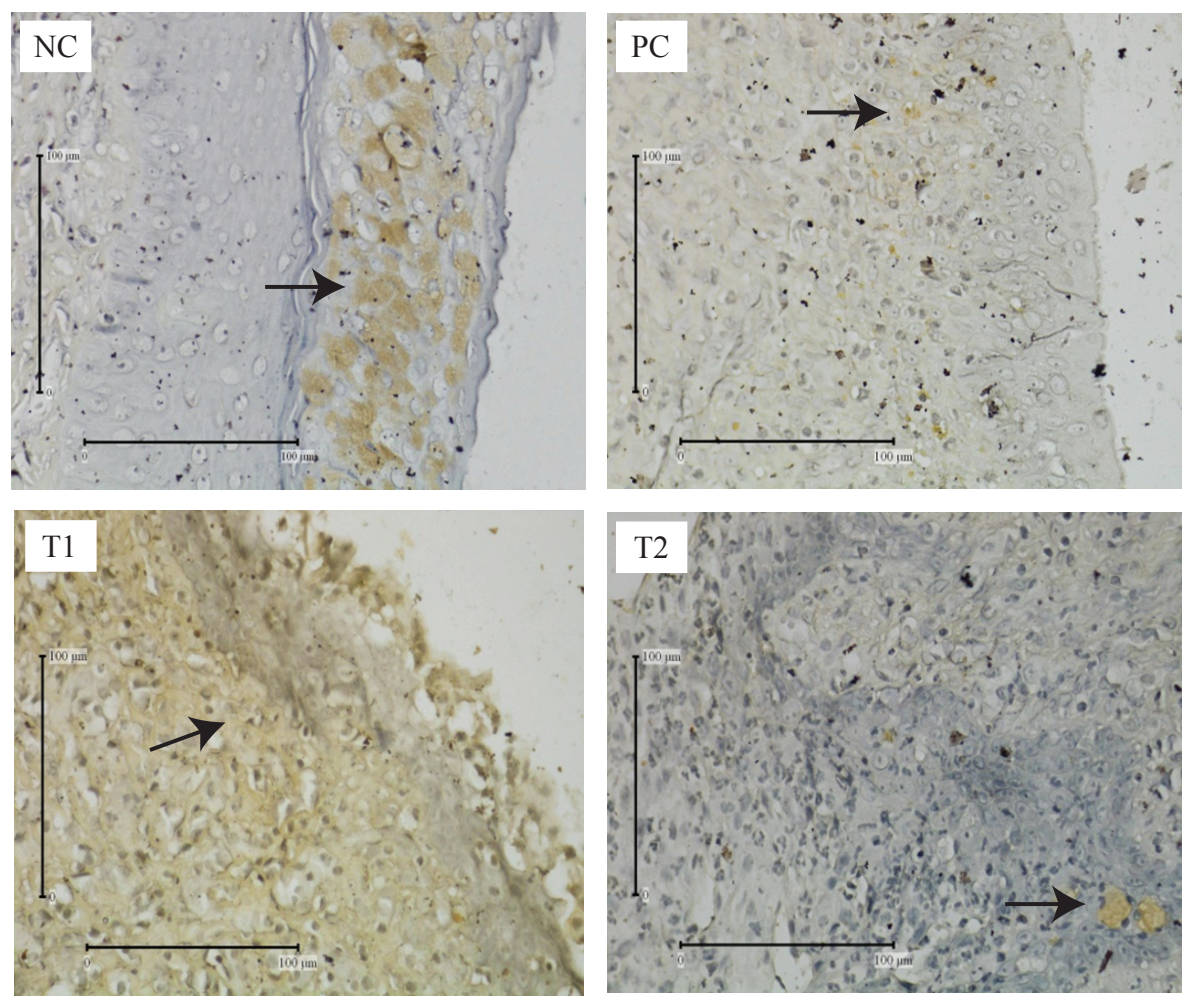

Figure 1. Ki-67 expression in the vaginal mucosa. The black arrow is $\mathrm{Ki}-67$ expression (brown chromogenic), IHC staining, 400x magnification; Nikon H600L microscope; 300 megapixel camera DS Fi2. Black bar: $100 \mu \mathrm{m}$. 
Table 2. Multiple comparisons of epithelial thickness.

\begin{tabular}{|c|c|c|c|c|c|}
\hline \multirow{2}{*}{ Groups } & \multicolumn{4}{|c|}{ Tukey HSD } & \multirow{2}{*}{$p$-value } \\
\hline & NC & PC & T1 & $\mathbf{T 2}$ & \\
\hline $\mathrm{NC}(3283 \pm 6.41)$ & - & 0.086 & 0.156 & 0.586 & \multirow{4}{*}{$0.003^{*}$} \\
\hline $\mathrm{PC}(21.19 \pm 3.96)$ & & - & 0.988 & $0.006^{*}$ & \\
\hline T1 $(22.66 \pm 6.63)$ & & & - & $0.012 *$ & \\
\hline $\mathrm{T} 2(38.73 \pm 12.43)$ & & & & - & \\
\hline
\end{tabular}

*Significancy value $p<0.05$, was tested with ANOVA test. NC: negative control group; PC: positive control group; T1: the first treatment group; T2: the second treatment group.

\section{Discussion}

Loss of the ovaries ability to produce estrogen during menopause results in the decreased of epithelial cell proliferation and maturation of vaginal epithelial cells. The first vaginal epithelial cell that stops growing is superficial cells followed by intermediate cells. Eventually the vaginal epithelium consists of parabasal or basal cells result in thinning of the vaginal epithelial wall.(5) $\mathrm{Ki}-67$ antigen is a nuclear protein that plays a role in cell proliferation which is associated with RNA transcription.(9) In this study was found that the lowest Ki-67 expression was the menopause group given distilled water. These findings indicate that there is a decrease of cell proliferation on menopausal conditions.
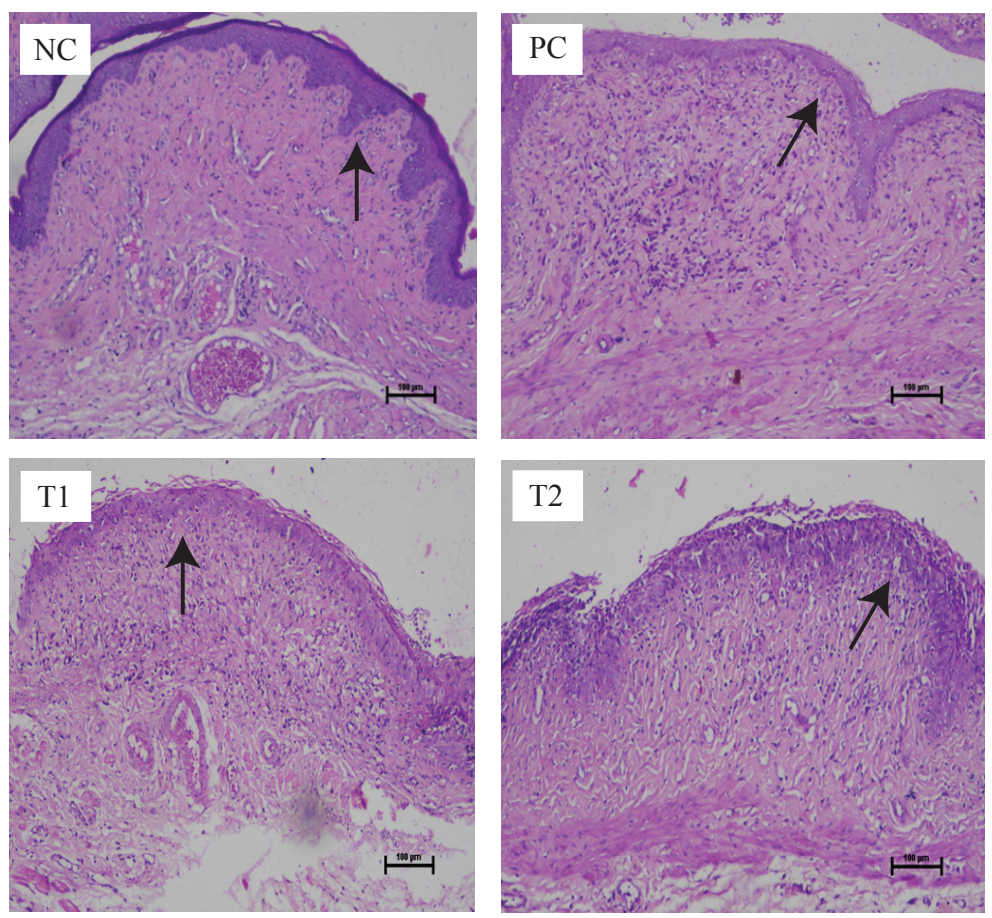

Tomato juice, contains lycopene, was phytoestrogens which bind to estrogen receptors and work similar to endogenous estrogen.(8) In this study, tomato juice increased the expression of $\mathrm{Ki}-67$ in the menopausal condition, although the increase did not reach normal conditions as in the NC. Increased expression of Ki-67 showed an increase proliferation on tomato juice administration, but statistically the differences of Ki-67 expression did not show significantly. Tomato juice did not significantly affect Ki-67 expression and Ki-67 expression also did not significantly affect the thickness of the vaginal wall epithelial layer. Based on these results, it can be assumed that tomato juice increase the cell proliferation of vaginal wall on menopause condition, but the increase is still within normal limits, unlike in malignancies whose cells are highly proliferative. The results of this study are similar to previous studies in
Figure 2. Epithelial thickness of the vaginal wall. The black arrow is the epithelial layer of vaginal wall (purple edge layer), HE staining, 100x magnification; Nikon Eclipse Ci. Black bar: $100 \mu \mathrm{m}$. 
cases of meningioma, are benign tumors in brain tissue or meninges, they found no significant relationship between $\mathrm{Ki}-67$ receptor status and progesterone which is considered to play a role in the proliferation of meningiomas, although high Ki-67 expression was found on positive progesterone receptors.(13)

The results of this study is different from previous studies conducted in malignant cases which found that Ki-67 expression is closely related to cell proliferation. $(10,11) \mathrm{Ki}-67$ monoclonal antibodies react with tumor cell nucleus antigens and is expressed only in proliferative cells. Therefore using Ki-67 monoclonal antibodies can be detected cell proliferation.(14-16) Previous study found that $\mathrm{Ki}-67$ is one of the immunohistochemistry markers which can be used to differentiate benign and malignant solitary thyroid nodule (STN) cases, and these markers also be used for a definite diagnosis of thyroid papillary carcinoma (PTC) with histopathological examination.(17) Expression of Ki-67 is associated with histopathological parameters. High expression of Ki-67 is an additional independent prognostic parameter of breast cancer patients for diseasefree survival and overall survival.(18) Results of this study were tomato juice increase cell proliferation in menopausal conditions, but its progression is not the same as malignancy. Afiati and Hernowo in their study found that high Ki-67 expression with strong intensity was only seen in highgrade liposarcoma and high Ki-67 expression associated with tumor progression.(14) Haroon found that Ki-67 was sensitive to high grade tumors.(16) Meanwhile another study, found a correlation between increased proliferating cell nuclear antigen (PCNA) and Ki-67 expression with histological features and tumor metastasis.(19) The higher the proliferation, the higher the level of $\mathrm{Ki}-67$ expression in stage IB2 and IIA2 cervical carcinoma.(20)

The vaginal mucosa consists of squamous epithelium and lamina propria. The vaginal wall epithelial consists of superficial cells, intermediate cells, parabasal cells and basal cells. Estrogen stimulates the development of squamous epithelial cells. The maturation index measures qualitatively the response of estrogen and quantitatively measures estrogen levels. The maturation index is the number of parabasal cells (P), intermediate cells (I) and superficial cells (S). The dominance of superficial cells shows the strong effects of estrogen, the dominance of parabasal cells shows a weak effect of estrogen.(5) Estrogen deficiency changes the maturation of epithelial cell, so the epithelial layer consists mostly of parabasal cells, which results in decreased glycogen content. The glycogen reduction in the vaginal epithelial causes the vaginal $\mathrm{pH}$ to become more alkaline, so increased vaginal inflammatory response and risk of infection or atrophic vaginitis. $(2,5,6)$ Decreasing estrogen levels in menopause cause thinning of the vaginal mucosal epithelium and vaginal wall atrophy due to decreased epithelial cell proliferation. This is similar to our results, that the lowest vaginal epithelial thickness was in menopausal model rats given distilled water.

Tomato juice as phytoestrogens will fill estrogen receptors on the vaginal wall. Estrogen acts on estrogen receptive cells to stimulate proliferation and maturation, through increased estrogen receptors. Estradiol is thought to react directly to the epithelium or the vaginal cell epithelial mitogenesis process. The ability of transcription induces squamous cell proliferation and maturation, resulting in thickening of the vaginal epithelium.(8)

This study found that tomato juice significantly increased the epithelial thickness of the vaginal wall. This shows that tomato juice containing phytoestrogens affects proliferation of the vaginal wall epithelial causing an increase in the thickness of the vaginal wall epithelial. Similar to previous studies, Prasetya and Raden, found that there was an increase in the thickness and elasticity of the vaginal wall in menopausal model rats given phytoestrogens.(12,21) Phytoestrogens stimulate glycogen formation. Lactobacilus Döderlein, part of the normal flora of the vagina, converts glycogen to lactic acid, making the vaginal $\mathrm{pH}$ remain acidic, thereby reducing the entry of pathogenic microorganisms. $(12,21)$

Estrogen increases the ability of basal cells in the vaginal epithelium to store glycogen.(5) Epithelial cells synthesize and collect glycogen. When cells are released, the lactobacillus bacteria will metabolize glycogen to lactic acid which causes vaginal $\mathrm{pH}$ to be around 4.5. Vaginal acidity provides protection against infection and some anaerobic microorganisms and pathogens.(2)

\section{Conclusion}

Based on the results of this study we concluded that tomato juices significantly increased vaginal wall epithelial thickness in menopausal rats. The increase of epithelial thickness follows dose administration. Tomato juice increases Ki-67 expression of menopausal rats. Tomato juice increases the cell proliferation of vaginal wall on menopause condition, but the increase is still within normal limits, unlike in malignancies whose cells are highly proliferative. 


\section{References}

1. Sturdee DW, Panay N, International Menopause Society Writing Group. Recommendations for the management of postmenopausal vaginal atrophy. Climacteric. 2010; 13: 509-22.

2. Immanuel AI, Wantania J, Suparman E, Lintong P. Clinical appearance and vaginal cytology of atrophic vaginitis in postmenopausal women. Indonesian J Obstet Gynecol. 2010; 34: 92-6.

3. Matthes ACS, ZuccaMatthes G, Oliveira MA. The genito urinary syndrome of menopause presents sexual symptoms that can be best explained by the relative short vagina syndrome. Gynecol Obstet (Sunnyvale). 2016; 6: 382. doi:10.4172/2161-0932.1000382.

4. Saimin J, Wicaksono S, Junuda, Minarti. Factors affecting the development of anxiety in postmenopausal women: a cross sectional study in coastal areas. Maj Obstet Ginekol Indones. 2018; 6: 133-6.

5. Amran R. Menentukan menopause berdasarkan indeks maturasi dan pH vagina. Jurnal Kedokteran \& Kesehatan. 2010; 42: 2981-6.

6. Grady D. Management of menopausal symptoms. N Engl J Med. 2006; 355: 2338-47.

7. Putra LM, Laswati. Natural phytoestrogen contents in several fruits and leafs; the future replacement hormone therapy in menopause women. Jurnal Cakrawala. 2011; 6: 88-95.

8. Bjornstrom L, Sjoberg M. Mechanism of estrogen receptor signaling: convergence of genomic and nongenomic actions on target genes. Mol Endocrinol. 2005; 19: 833-42.

9. Bullwinkel J, Baron-Lühr B, Lüdemann A, Wohlenberg C, Gerdes J, Scholzen T. Ki-67 protein is associated with ribosomal RNA transcription in quiescent and proliferating cells. J Cell Physiol 2006; 206: 624-35.

10. Lin MX, Wen ZF, Feng ZY, He D. Expression and significance of BMI and Ki67 in coclorectal carcinoma. Ai Zheng. 2008; 27: 1321-6.

11. Yulianti H, Hernowo BS. Hubungan antara imunoekspresi Ki-67 dan risiko agresivitas tumor pada gastrointestinal stromal tumor. Majalah Kedokteran Bandung. 2015; 47; 231-6.
12. Prasetya A, Widjayanti Y. Effect of tomato juice on vaginal wall elasticity in menopausal rats. Folia Medica Indonesia. 2015; 51: 132-6.

13. Tandean S, Indharty S, Japardi I, Sufida. Hubungan antara reseptor progesteron dengan Ki-67 labeling index pada meningioma. Majalah Kedokteran Nusantara. 2013; 46: 17-20.

14. Afiati, Hernowo BS. Hubungan ekspresi Ki-67 dengan grading histopatologi liposarkoma. Majalah Kedokteran Bandung. 2013; 45: 187-91.

15. Dowsett M, Nielsen TO, Bartlett RAJ, Coombes RC, Cuzick J, Ellis M. Assessment of Ki67 in breast cancer: recommendations from the international Ki67 in breast cancer working group. J Natl Cancer Inst. 2011; 103: 1656-64.

16. Haroon S. Ki67 Index in breast cancer: correlation with other prognostic markers and potential in Pakistani patients. Asian Pac J Cancer Prev. 2013; 14: 4353-8.

17. Dwivedi SS, Khandeparkar SGS, Joshi AR, Kulkarni MM, Bhayekar $\mathrm{P}$, Jadhav A, et al. Study of immunohistochemical markers (CK19 , CD-56, Ki-67, p53) in differentiating benign and malignant solitary thyroid nodules with special reference to papillary thyroid carcinomas. J Clin and Diagn Res. 2016; 10: 14-9.

18. Inwald EC, Klinkhammer-Schalke M, Hofstadter F, Zeman F, Koller $\mathrm{M}$, Gerstenhauer M, et al. $\mathrm{Ki}-67$ is a prognostic parameter in breast cancer patients: results of a large population-based cohort of a cancer registry. Breast Cancer Res Treat. 2013; 139: 539-52.

19. Aydin O, Ersoz C, Ozbarlas S, Seydaoglu G. Assessment of proliferative activity in soft tissue sarcomas showing PCNA and Ki67 reactivity immunohistochemically. Turk J Med Sci. 2000; 30; 261-9.

20. Mahayasa IMW, Tobing MDL, Harsono AB. Hubungan antara Ekspresi Ki-67 dan Kaspase-3 dengan Respons Kemoterapi Neoajuvan pada Pasien Karsinoma Serviks Stadium IB2 dan IIA2 di Rumah Sakit Dr. Hasan Sadikin, Bandung. Indonesian J Cancer. 2016; 10: 49-54.

21. Raden A. Effect of pegagan (Centella asiatica) extract in ovariectomized wistar-strain rattus norvegicus on epithelial proliferation of vaginal wall. Jurnal Ilmiah Kedokteran Hewan. 2011; 4: 71-6. 